\title{
Sites of Failure in Breast Cancer Patients with Extra- capsular Invasion of Axillary Lymph Node Metastases
}

\author{
No Need for Axillary Irradiation?! \\ Günther Gruber', Samuel Menzi', Andrea Forster', Gilles Berclaz², Hans-Jörg Altermatt³ \\ Richard H. Greiner ${ }^{1}$
}

\begin{abstract}
Background and Purpose: Extracapsular spread (ECS) is frequent, but the specific sites of relapse are seldom given in the literature. In this study it was evaluated, if ECS might be an indicator for axillary irradiation.

Patients and Methods: After a retrospective review of pathology reports, the information about ECS was available in 254 lymph node-positive patients: ECS was absent in $34 \%$ (ECS-negative; $n=87$ ) and present in $66 \%$ (ECS-positive; $n=167$ ). All patients were irradiated locally, 78 patients got periclavicular and 74 axillary irradiation (median total dose: 50.4 Gy). $240 / 254$ patients $(94.5 \%)$ received systemic treatment/s. Mean follow-up was 46 months.

Results: The regional relapse rate was $4.6 \%$ without ECS versus $9.6 \%$ with ECS. The 5 -year axillary relapse-free survival was $100 \%$ in ECS-negative and $90 \%$ in ECS-positive patients $(p=0.01)$, whereas corresponding values for periclavicular relapse-free survival (with ECS: $91 \% \pm 4 \%$; without ECS: $94 \% \pm 3 \% ; p=0.77$ ) and local relapse-free survival (with ECS: $86 \% \pm 4 \%$; without ECS: $91 \% \pm$ $3 \% ; p=0.69$ ) were not significantly different. $\chi^{2}$-tests revealed a high correlation of ECS with T-stage, number of positive lymph nodes and progesterone receptor status, comparisons with estrogen receptor, grade, or age were not significant. In multivariate analysis number of positive lymph nodes was solely significant for regional failure. Dividing the patients into those with one to three and those with four or more positive lymph nodes, ECS lost its significance for axillary failure.

Conclusion: ECS was accompanied by an enhanced axillary failure rate in univariate analysis, which was no longer true after adjusting for the number of positive lymph nodes.
\end{abstract}

Key Words: Extranodal · Pattern of failure $\cdot$ Axillary failure

Strahlenther Onkol 2005;181:574-9

DOI $10.1007 / \mathrm{s} 00066-005-1367-x$

\section{Rückfallmuster beim nodal positiven Mammakarzinom mit extrakapsulärer Ausdehnung. Kein Grund zur Axilla- bestrahlung?!}

Hintergrund und Ziel: Extrakapsuläres Tumorwachstum (ECS) befallener axillärer Lymphknoten ist häufig und wird als Parameter einer erhöhten lokoregionären Rezidivrate angesehen. In der Literatur sind erstaunlich wenig Informationen bezüglich spezifischer Lokalisationen eventueller Rezidive erhältlich. In dieser Studie sollte das ECS als eventuelle Indikator für eine Bestrahlung der Axilla evaluiert werden.

Patienten und Methodik: Es wurden nur jene 254 nodal positiven Patientinnen ausgewertet, bei denen gemäß histologischem Bericht zum Vorliegen oder Fehlen von ECS klar Stellung genommen wurde: In 66\% (ECS-positiv; $n=167$ ) wurde ECS beschrieben, und in $34 \%$ fehlte es (ECS-negativ; $n=87$ ). Alle Patientinnen wurden lokal bestrahlt, 78 davon auch periklavikulär und 74 axillär (mediane Gesamtdosis: je 50,4 Gy). 240/254 Patientinnen (94,5\%) erhielten Systemtherapie/n. Die mittlere Nachbeobachtungszeit betrug 46 Monate.

Ergebnisse: Die regionäre Rezidivrate betrug $4,6 \%$ ohne ECS versus $9,6 \%$ mit ECS. Das axilläre rezidivfreie 5 -Jahres-Überleben war $100 \%$ bei ECS-negativen und $90 \%$ bei ECS-positiven Patientinnen $(p=0,01)$. Die korrespondierenden Werte für das periklavikuläre rezidivfreie Überleben (mit ECS: $91 \% \pm 4 \%$; ohne ECS: $94 \% \pm 3 \% ; p=0,77$ ) und das lokalrezidivfreie Überleben (mit ECS: $86 \% \pm 4 \%$; ohne ECS: $91 \% \pm 3 \% ; p=0,69$ ) waren nicht signifikant unterschiedlich. ECS (ja/nein) korrelierte signifikant mit dem T-Stadium, der Anzahl positiver Lymphknoten und dem Progesteronrezeptorstatus, dagegen nicht mit dem Östrogenrezeptor, dem Tumorgrad oder dem Alter. Multivariat war die Anzahl positiver Lymphknoten der einzige signifikante Parameter für das regionale

\footnotetext{
${ }^{1}$ Department of Radiation Oncology, Inselspital, University of Berne, Switzerland,

${ }^{2}$ Department of Gynecology, Inselspital, University of Berne, Switzerland,

${ }^{3}$ Institute of Pathology, Berne, Switzerland.
}

Received: October 5, 2004; accepted: June 23, 2005 
Tumorrezidiv. Nach der Stratifikation der Patientinnen in solche mit ein bis drei und solche mit vier oder mehr positiven Lymphknoten ließ sich keine Signifikanz von ECS für die axilläre Rezidivhäufigkeit mehr finden.

Schlussfolgerung: In der univariaten Analyse war das Vorliegen von ECS mit einer erhöhten axillären Rezidivhäufigkeit vergesellschaftet. Dies konnte nach Aufteilung in ein bis drei und vier oder mehr positive Lymphknoten nicht mehr beobachtet werden.

Schlüsselwörter: Extranodal · Rezidivmuster · Axilläres Versagen · Multivariat

\section{Introduction}

The presence of extracapsular spread (ECS) of axillary lymph node metastasis/metastases is often correlated with locoregional failure [11]. Therefore, ECS is considered to be an indication for axillary radiotherapy in some textbooks $[2,21]$. In fact, only few publications evaluated the prognostic role of ECS and even less reports deal with the different sites of relapse. A lot of controversy exists about the necessity of regional irradiation especially to the axilla. It is unclear, if the risk of axillary recurrence justifies the enhanced risk of toxicity (e.g., lymphedema, impaired shoulder movement) caused by irradiation to this site.

We aimed to compare the failure pattern in node-positive breast cancer patients related to the presence or absence of ECS with a special emphasis on axillary recurrence.

\section{Patients and Methods}

As the information of ECS is not always prospectively recorded in the pathology report, only lymph node-positive patients with a clear definition of the presence or absence of ECS were eligible for this retrospective review. ECS was defined as any breech of the capsule of one or more metastatic lymph node/s.

Between 08/1988 and 12/2001, 254 node-positive breast cancer patients with a median age of 56 years (range: 26-87 years) could be identified, 167 (66\%) of them with ECS. All patients had segmental mastectomy with axillary node dissection (level I, II, \pm III; $\mathrm{n}=144$ ) or modified radical mastectomy $(\mathrm{n}=110)$. The median number of resected lymph nodes was 17 (range: one to 68), of which a median of three (range: one to 49$)$ were positive. In eleven patients $(4 \%)$ the total number of lymph nodes could not exactly be defined because of conglomeration. According to the pathologic report "many lymph nodes were metastatic", and these patients were included in the subgroup with more than three positive lymph nodes for further analyses. No patient had evidence of distant metastasis after staging which included routine chest X-rays, blood tests, liver ultrasounds, bone scans, and, in several cases, computed tomographies of the thorax.

240 out of 254 patients $(94.5 \%)$ received systemic adjuvant treatment/s: 160 hormonal treatment (154 tamoxifen; six toremifen), and 204 chemotherapy. The chemotherapeutic regimens were anthracycline-based in 120 patients (in combination with taxanes in seven patients and with CMF in 61 patients). 84 patients received chemotherapy with CMF only.

Radiotherapy was applied in every patient. The clinical target volume (CTV) enclosed the chest wall or the breast without defined inclusion of the lymph node regions in 176 patients with a median total dose of 50.4 Gy (range: 32.6-66.6 Gy). In 78 patients the periclavicular region and in 74 of these patients the axillary region were irradiated with a median dose of $50.4 \mathrm{~Gy}$. A boost with a median dose of 10 Gy was applied in 93 patients. No special attempt was undertaken to include the lymph nodes of the mammaria interna region.

Table 1 summarizes the clinicopathologic characteristics stratified according to the presence or absence of ECS.

\section{Statistical Methods}

Cross tabulations between ECS-positive and ECS-negative patients in regard to clinicopathologic parameters were cal-

Table 1. Distribution of clinicopathologic parameters in patients with or without extracapsular spread (ECS).

Tabelle 1. Verteilung klinischer und pathologischer Parameter bei Patientinnen mit oder ohne extrakapsuläres Wachstum (ECS).

\begin{tabular}{|c|c|c|c|}
\hline $\begin{array}{l}\text { All patients } \\
n=254\end{array}$ & $\begin{array}{l}\text { With ECS } \\
\mathrm{n}=167 \\
(66 \%) \\
\mathrm{n}(\%)\end{array}$ & $\begin{array}{l}\text { Without ECS } \\
n=87 \\
(34 \%) \\
n(\%)\end{array}$ & $\begin{array}{l}\text { p-value } \\
\text { (two-sided) }\end{array}$ \\
\hline Age $\leq 50$ years & $49(29)$ & $36(41)$ & 0.068 \\
\hline Age $>50$ years & $118(71)$ & $51(59)$ & \\
\hline $\begin{array}{l}\text { Grade } 1 \\
\text { Grade } 2 \\
\text { Grade } 3 \\
\text { Grade } x\end{array}$ & $\begin{array}{r}2(1) \\
93(56) \\
65(39) \\
7 \quad(4)\end{array}$ & $\begin{array}{r}2(2) \\
52(60) \\
28(32) \\
5 \quad(6)\end{array}$ & 0.52 \\
\hline $\begin{array}{l}\text { Estrogen receptor negative } \\
\text { Estrogen receptor positive }\end{array}$ & $\begin{array}{r}53(32) \\
114(68)\end{array}$ & $\begin{array}{l}22(25) \\
65(75)\end{array}$ & 0.31 \\
\hline $\begin{array}{l}\text { Progesterone receptor negative } \\
\text { Progesterone receptor positive }\end{array}$ & $\begin{array}{r}65(39) \\
102(61)\end{array}$ & $\begin{array}{l}22(25) \\
65(75)\end{array}$ & 0.036 \\
\hline $\begin{array}{l}\text { T-stage } 1+2 \\
\text { T-stage } 3+4\end{array}$ & $\begin{array}{r}112(67) \\
55(33)\end{array}$ & $\begin{array}{l}75(86) \\
12(14)\end{array}$ & 0.001 \\
\hline $\begin{array}{l}\text { Positive nodes } \\
\text { - } 1-3 \\
-\geq 4\end{array}$ & $\begin{array}{r}61(37) \\
106(63)\end{array}$ & $\begin{array}{l}70(80) \\
17(20)\end{array}$ & $<0.001$ \\
\hline $\begin{array}{l}\text { Radiotherapy } \\
\text { - Local only } \\
\text { - Locoregional }\end{array}$ & $\begin{array}{l}83(50) \\
84(50)\end{array}$ & $\begin{array}{r}82(94) \\
5 \quad(6)\end{array}$ & $<0.001$ \\
\hline $\begin{array}{l}\text { Systemic therapy } \\
\text { - No } \\
\text { - Hormonal therapy } \\
\text { - Chemotherapy } \\
\text { - Hormonal therapy/chemotherapy }\end{array}$ & $\begin{array}{c}9(6) \\
23(14) \\
44(26) \\
91(54)\end{array}$ & $\begin{array}{l}5(6) \\
13(15) \\
36(41) \\
33(38)\end{array}$ & 0.061 \\
\hline
\end{tabular}

adone by Fisher's exact test or Pearson's $\chi^{2}$-test

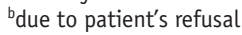


Table 2. Pattern of failure in patients with or without extracapsular spread (ECS). A: axillary; I: infraclavicular; S: supraclavicular. Tabelle 2. Rezidivmuster von Patientinnen mit oder ohne extrakapsuläres Wachstum (ECS). A: axillär; I: infraklavikulär; S: supraklavikulär.

\begin{tabular}{|c|c|c|c|}
\hline Site of first failure & $\begin{array}{l}\text { All patients } \\
\mathrm{n}=254 \\
\mathrm{n}(\%)\end{array}$ & $\begin{array}{l}\text { Without ECS } \\
n=87 \\
n(\%)\end{array}$ & $\begin{array}{l}\text { With ECS } \\
n=167 \\
n(\%)\end{array}$ \\
\hline Local only & $6 \quad(2.4)$ & $4(4.6)$ & $2(1.2)$ \\
\hline Regional only & $1(0.4)(1 \times I)$ & $1(1.1)(1 \times I)$ & 0 \\
\hline Distant only & $45(17.7)$ & $8(9.2)$ & $37(22.2)$ \\
\hline Local + regional & 0 & 00 & \\
\hline Local + distant & $5(2.0)$ & $2(2.3)$ & $3(1.8)$ \\
\hline Regional + distant & $4(1.6)(2 \times A ; 2 \times S)$ & $0 \quad 4 \quad(2.4)(2 \times A ; 2 \times S)$ & \\
\hline Local + regional + distant & $15(5.9)(3 \times A+S ; 5 \times S ; 1 \times I ; 6 \times A)$ & $3(3.4)(3 \times S)$ & 12 (7.2) $(3 \times \mathrm{A}+\mathrm{S} ; 2 \times \mathrm{S} ; 1 \times \mathrm{I} ; 6 \times \mathrm{A})$ \\
\hline All local & $26(10.2)$ & $9(10.3)$ & $17(10.2)$ \\
\hline All regional & $20(7.9)$ & $4(4.6)$ & $16(9.6)$ \\
\hline All distant & $69(27.2)$ & $13(15.0)$ & $56(33.5)$ \\
\hline
\end{tabular}

culated using Fisher's exact test or Pearson's $\chi^{2}$-test. Recurrence was divided into local, axillary, periclavicular (= supraclavicular + infraclavicular), and distant. The Kaplan-Meier method was used for the estimation of survival times, and the log-rank test for univariate analyses of various parameters as to local relapse-free survival (LRFS), axillary relapse-free survival (ARFS), periclavicular relapse-free survival (PRFS), and distant metastasis-free survival (DMFS). Regional failure (= axillary + periclavicular failure) was of special interest, and all factors were also evaluated in multivariate analysis for this endpoint using the Cox regression

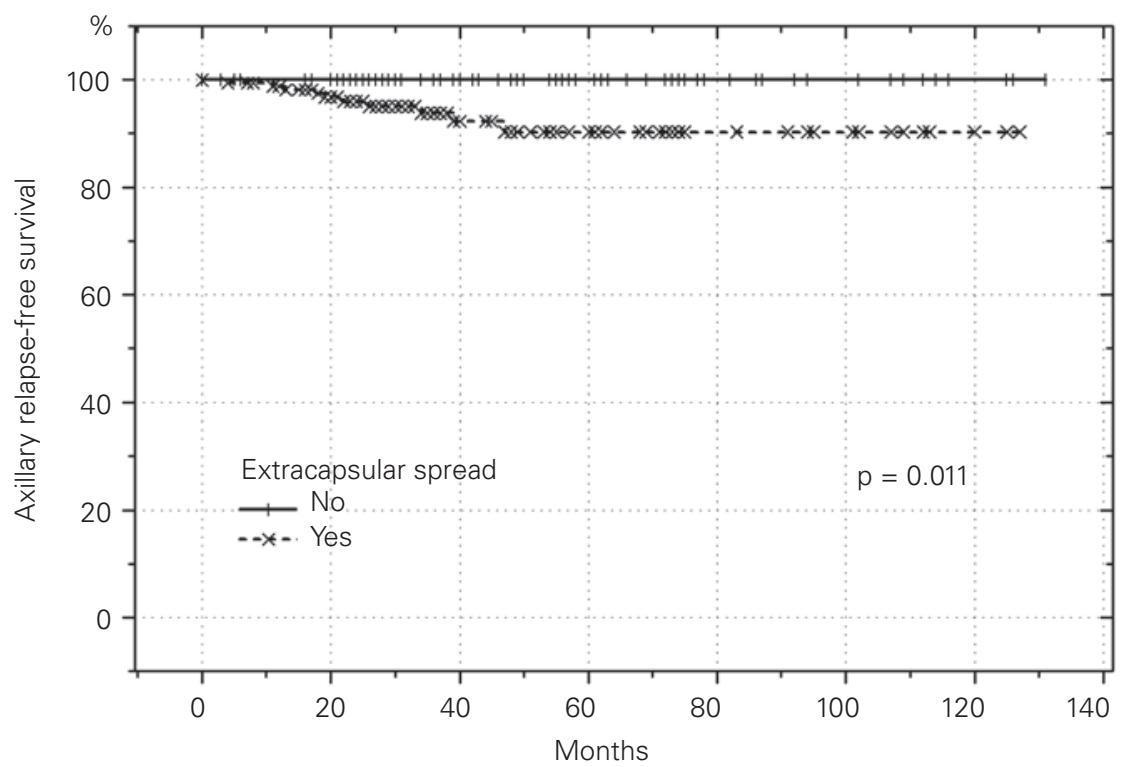

Figure 1. Axillary relapse-free survival in 254 node-positive patients according to extracapsular spread.

Abbildung 1. Axilläres rezidivfreies Überleben bei 254 nodal positiven Patientinnen in Abhängigkeit vom extrakapsulären Wachstum. proportional hazard model. A p-value $<0.05$ was considered statistically significant.

\section{Results}

ECS was present in $66 \%$ of patients. Patients with ECS had more T3/T4 tumors $(p=0.001)$, a higher number of positive lymph nodes $(\mathrm{p}<0.001)$ and more often progesterone receptor-negative tumors $(\mathrm{p}=0.036)$. There was also a high imbalance regarding the treatment field selection of postoperative radiotherapy, as in general, patients without ECS were irradiated only locally $(\mathrm{p}<0.001)$. No significant difference could be observed in relation to age, grade, estrogen receptor or the use of systemic therapies. Details of the different patient characteristics are given in Table 1.

\section{Sites of First Failure (Table 2)}

After a mean follow-up of 46 months, 26 patients relapsed locally. Local failures were equally distributed in both groups (with ECS: 17/167, 10.2\%; without ECS: 9/87, 10.3\%). Regional failures occurred in 20 patients $(7.9 \%)$ : axillary in eight, supraclavicular in seven, axillary + supraclavicular in three, infraclavicular in two patients. There was no failure in the mammary chain region.

The regional relapse rate was $4.6 \%$ in patients without ECS versus $9.6 \%$ in patients with ECS. No axillary failure could be observed in the absence of ECS. Distant failures were also less frequent in patients without ECS, $15 \%$ and $33.5 \%$, respectively. 


\section{Survival Analyses}

The 5-year regional relapse-free survival (RRFS) was $94 \%$ $\pm 3 \%$ for patients without and $84 \% \pm 4 \%$ for patients with ECS $(p=0.07)$. Dividing regional failures to specific sites, the ARFS was significantly decreased in patients with ECS. The 5-year ARFS for these patients was $90 \% \pm 3 \%$ compared to $100 \%$ in patients without ECS $(\mathrm{p}=0.01$; Figure 1$)$. There was no significant difference in the 5-year PRFS (with ECS: $91 \% \pm 4 \%$; without ECS: $94 \% \pm$ $3 \% ; \mathrm{p}=0.77$; Figure 2) and the 5-year LFRS (with ECS: $86 \% \pm 4 \%$; without ECS: $91 \% \pm 3 \%$; $p=0.69$; Figure 3).

Multivariate analysis for regional failure using Cox regression analysis was subsequently performed (Table 3 ). The only significant factor was the number of positive lymph nodes $(\mathrm{p}=0.007)$, whereas other parameters like ECS or radiation treatment volume were not significant.

The next step to evaluate the role of ECS for axillary and periclavicular failure was to divide the patients into two subgroups according to the number of positive lymph nodes. There were 131 patients with one to three, and 123 patients with four or more positive nodes. We could not detect a significant difference in patients with or without ECS in both subgroups; however; the p-value for axillary failure was 0.07 in patients with one to three positive nodes (Figure 4).

\section{Discussion}

The likelihood of ECS rises with the number of positive lymph nodes [24]. In our series ECS was found in $47 \%$ of patients with one to three nodes, but in $86 \%$ of patients with four or more nodes. This positive correlation was highly significant and goes in line with a previous examination [7] and other data in the literature $[1,3,9,13]$. This is probably the main reason why an independent prognostic role of ECS is difficult to determine.

First reports which found a correlation of ECS with decreased survival were published nearly 30 years ago [5, $13]$ and have been confirmed by almost every study afterwards $[1,3,10,12,14,18$, 20]. Leonard et al. [12] showed that ECS capsular spread. spread. and number of positive lymph nodes were both independent factors for decreased survival. Pierce et al. [18] reported on a three times higher risk of death for patients with ECS after adjusting for the number of positive nodes $(p=0.06)$. In a se-

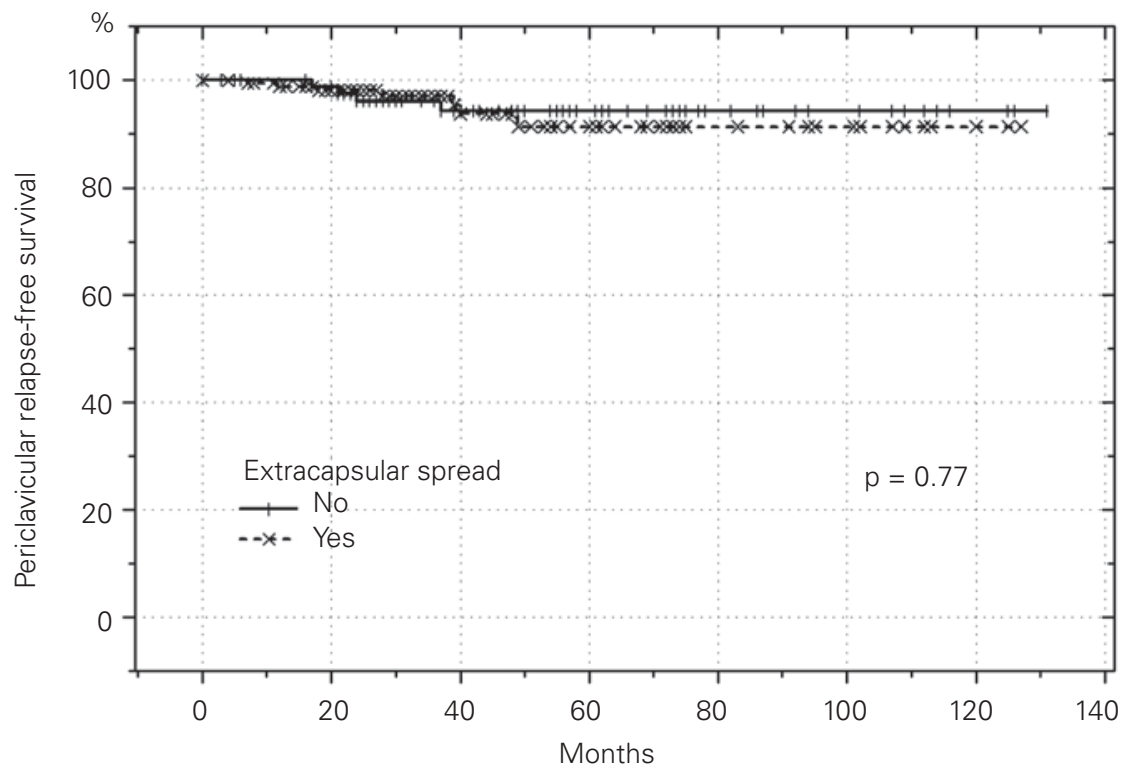

Figure 2. Periclavicular relapse-free survival in 254 node-positive patients according to extra-

Abbildung 2. Periklavikuläres rezidivfreies Überleben bei 254 nodal positiven Patientinnen in Abhängigkeit vom extrakapsulären Wachstum.

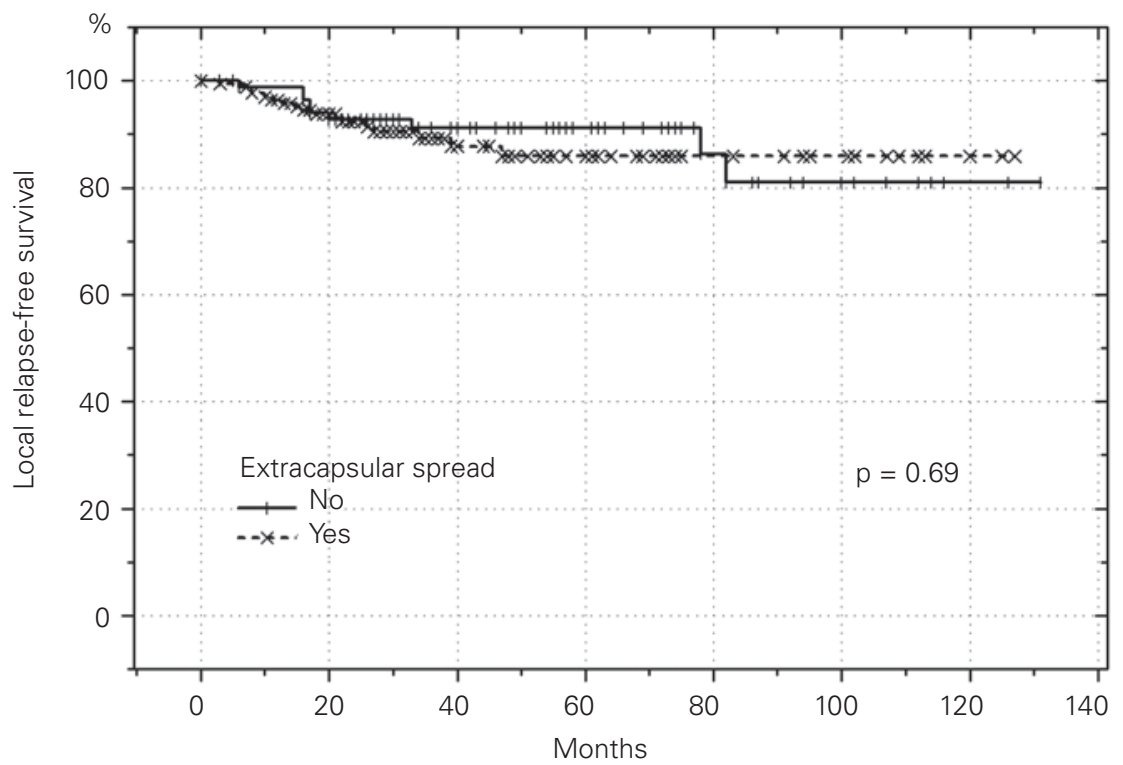

Figure 3. Local relapse-free survival in 254 node-positive patients according to extracapsular

Abbildung 3. Lokales rezidivfreies Überleben bei 254 nodal positiven Patientinnen in Abhängigkeit vom extrakapsulären Wachstum. 
ries with 483 node-positive patients of whom 219 presented ECS, Kahlert et al. [10] found that this pathologic feature was significant in multivariate analysis with a relative risk of 1.6. This figure is similar to the risk ratio of $1.77(\mathrm{p}=0.1)$ and 1.7

Table 3. Multivariate analysis (Cox regression proportional hazard) for "regional failure". Cl: confidence interval; CT: chemotherapy; HT: hormonal therapy; RR: relative risk.

Tabelle 3. Multivariate Analyse („Cox regression proportional hazard“) für „regionales Rezidiv“. Cl: Konfidenzintervall; CT: Chemotherapie; HT: Hormontherapie; RR: relatives Risiko.

\begin{tabular}{lll}
\hline Parameter & p-value & RR (95\% CI) \\
\hline $\begin{array}{l}\text { Number of positive nodes } \\
(1-3 ; \geq 4)\end{array}$ & 0.007 & $0.25(0.09-0.68)$ \\
$\begin{array}{l}\text { Age } \\
(>50 \text { years; } \leq 50 \text { years) }\end{array}$ & 0.27 & $0.60(0.24-1.48)$ \\
$\begin{array}{l}\text { Estrogen receptor } \\
\text { (positive; negative) }\end{array}$ & 0.14 & $0.52(0.21-1.24)$ \\
$\begin{array}{l}\text { Progesterone receptor } \\
\text { (positive; negative) }\end{array}$ & 0.82 & $0.89(0.32-2.45)$ \\
$\begin{array}{l}\text { T-stage } \\
\text { (T1/2; T3/4) }\end{array}$ & 0.30 & $0.55(0.18-1.69)$ \\
$\begin{array}{l}\text { Grade } \\
\text { (G1; G2; G3; Gx) }\end{array}$ & 0.89 & $1.05(0.50-2.24)$ \\
$\begin{array}{l}\text { Extracapsular spread } \\
\text { (yes; no) }\end{array}$ & 0.62 & $1.38(0.39-4.34)$ \\
$\begin{array}{l}\text { Systemic therapy } \\
\text { (no; CT; HT; CT + HT) }\end{array}$ & 0.43 & $0.81(0.48-1.37)$ \\
$\begin{array}{l}\text { Radiotherapy } \\
\text { (local; locoregional) }\end{array}$ & 0.15 & $2.14(0.77-5.96)$ \\
\hline
\end{tabular}

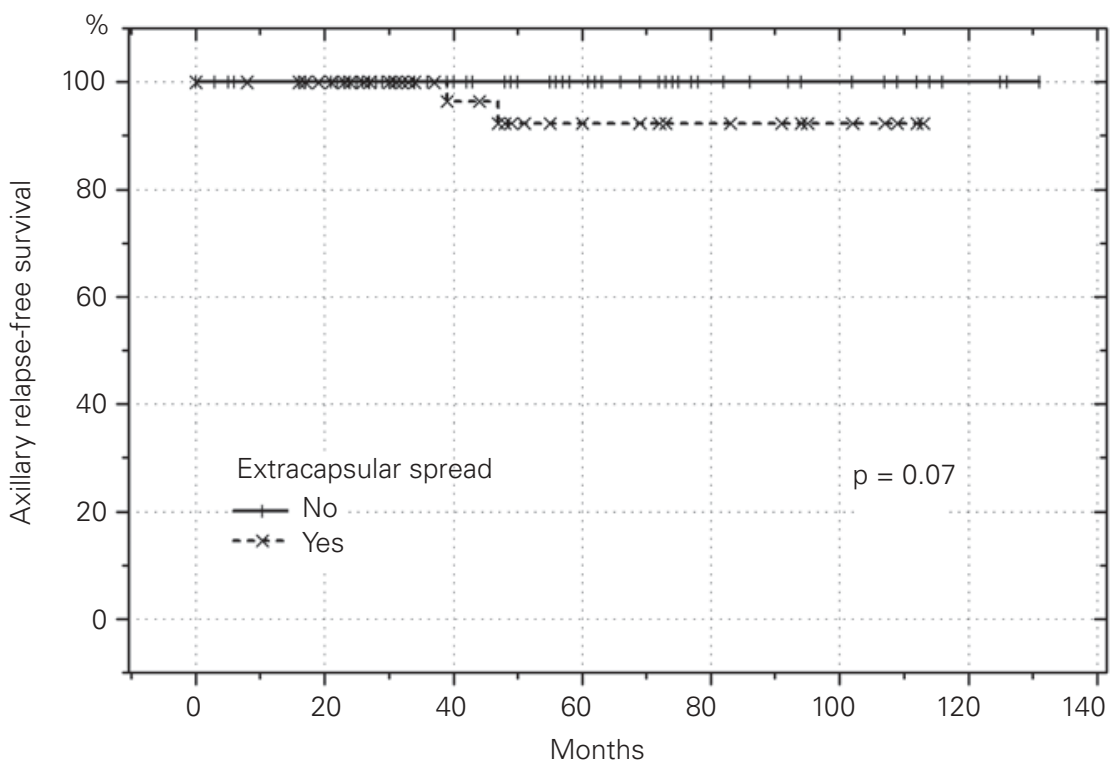

Figure 4. Axillary relapse-free survival in 131 patients with one to three positive lymph nodes according to extracapsular spread.

Abbildung 4. Axilläres rezidivfreies Überleben bei 131 Patientinnen mit ein bis drei positiven Lymphknoten in Abhängigkeit vom extrakapsulären Wachstum. $(\mathrm{p}=0.1)$ in two other studies $[3,14]$. The interpretation, however, is difficult, as they all differ in patient selection and the use of both, radiotherapy and systemic treatments. The same is true for the current study, but all of our patients got irradiation and nearly $95 \%$ also systemic therapy.

If we assume that all node-positive breast cancer patients should receive postoperative radiotherapy after breast-conserving surgery $[15,26]$ and mastectomy $[16,17,19,27]$, the question remains about the necessity of regional irradiation, especially if ECS is present. There is a lack of information about the specific sites of locoregional failure in the literature. Our primary interest was the influence of ECS on axillary failure.

In general, axillary failure rates are low [22]: in patients without axillary irradiation 1/122 (0.8\%) [9], 1/43 (2.3\%) [1], $1 / 20$ (5\%) [12], 1/27 (3.7\%) [18], and 0/6 (0\%) [25] patients relapsed in the axilla. As parts of it are often encompassed by tangential chest/breast irradiation, series without any irradiation are more appropriate for failure rate definition, but even then axillary relapses are low: 0/62 (0\%) [3], 2/28 (7.1\%) [1], 6/82 (7\%) [4], 0/43 (0\%) [14], and 1/85 (1.2\%) [6]. We experienced eleven failures out of 167 ECS-positive patients $(6.6 \%)$. According to Kaplan-Meier plots, the actuarial axillary failure rate at 5 years was $10 \%$ versus $0 \%$ in the control group. There was no axillary failure even with four or more positive lymph nodes in the absence of ECS, and according to this result axillary irradiation can be omitted.

Patients with ECS experienced more axillary failures at least in univariate analysis, and despite the fact that patients with ECS got more often regional irradiation. To diminish this potential bias, a Cox regression analysis including the extent of irradiation (local vs. locoregional) was performed. The number of positive lymph nodes was the only significant factor for regional failure. Dividing the patients into those with one to three and those with four or more positive lymph nodes, ECS lost its prognostic value. Regional recurrence is uncommon in patients with one to three positive lymph nodes and ECS [23]. The number of positive lymph nodes might be much more important than ECS in the consideration of axillary irradiation.

Interestingly, all but one regional relapses were accompanied by distant failure. With few exceptions regional recurrences are likely to be an indicator of a systemic disease. It is questionable, if regional irradiation can alter the outcome in these patients.

Due to the retrospective design and a relatively small patient cohort firm conclusions cannot be made, but based 
on our findings and data from the literature we do not support axillary irradiation regardless if ECS is present or not. The inclusion of the axillary apex and subclavian area is appropriate for selected node-positive cases, particularly those with four or more positive nodes [8]. Ongoing and future studies have to demonstrate which patients might benefit from additional regional radiation treatment.

Despite the frequency of ECS in node-positive breast cancer data about the prognostic role of ECS are rare, and the current evaluation represents one of the largest in the literature. We could not find any significant differences in local or periclavicular relapse rates between ECS-positive and ECS-negative patients. In the absence of ECS there was no axillary relapse, and irradiation of the axilla can be omitted independent of the number of positive lymph nodes. In patients with ECS axillary failures are more common, but probably on the basis of a more aggressive disease. If adjuvant irradiation of the axilla or other lymph node regions can alter the prognosis is still an open field for investigation.

\section{References}

1. Bucci JA, Kennedy CW, Burn J, et al. Implications of extranodal spread in node positive breast cancer: a review of survival and local recurrence. Breast 2001;10:213-9.

2. Chao KSC, Perez CA, Brady LW, eds. Radiation oncology: management decisions. Philadelphia: Lippincott-Raven, 1999:347-67.

3. Donegan WL, Stine SB, Samter TG. Implications of extracapsular nodal metastases for treatment and prognosis of breast cancer. Cancer 1993;72:778-82.

4. Fisher BJ, Perera FE, Cooke AL, et al. Extracapsular axillary node extension in patients receiving adjuvant systemic therapy: an indication for radiotherapy? Int J Radiat Oncol Biol Phys 1997;38:551-9.

5. Fisher ER, Palekar AS, Gregorio RM, et al. Pathologic findings from the National Surgical Adjuvant Breast Project (protocol no. 4): III. The significance of extranodal extension of axillary metastases. Am J Clin Pathol 1976:65:439-44.

6. Fodor J, Toth J, Major T, et al. Incidence and time of occurrence of regional recurrence in stage I-II breast cancer: value of adjuvant irradiation. Int J Radiat Oncol Biol Phys 1999;44:281-7.

7. Gruber G, Berclaz G, Altermatt HJ, et al. Can the addition of regional radiotherapy counterbalance important risk factors in breast cancer patients with extracapsular invasion of axillary lymph node metastases? Strahlenther Onkol 2003;179:661-6.

8. Harris JR, Halpin-Murphy P, McNeese M, et al. Consensus statement on postmastectomy radiation therapy. Int J Radiat Oncol Biol Phys 1999;44: 989-90.

9. Hetelekidis S, Schnitt SJ, Silver B, et al. The significance of extracapsular extension of axillary lymph node metastases in early-stage breast cancer. Int J Radiat Oncol Biol Phys 2000;46:31-4.

10. Kahlert S, Boettcher B, Lebeau A, et al. Prognostic impact of extended extracapsular component in involved lymph nodes in primary breast cancer. Eur J Cancer 1999;35:Suppl 4:89. abstract 292.

11. Katz A, Strom EA, Buchholz TA, et al. Locoregional recurrence patterns after mastectomy and doxorubicin-based chemotherapy: implications for postoperative irradiation. J Clin Oncol 2000;18:2817-27.

12. Leonard C, Corkill M, Tomkin J, et al. Are axillary recurrence and overall survival affected by axillary extranodal tumor extension in breast cancer? Implications for radiation therapy. J Clin Oncol 1995;13:47-53.
13. Mambo NC, Gallager S. Carcinoma of the breast: the prognostic significance of extranodal extension of axillary disease. Cancer 1977;39:2280-5.

14. Mignano JE, Zahurak ML, Chakravarthy A, et al. Significance of axillary lymph node extranodal soft tissue extension and indications for postmastectomy irradiation. Cancer 1999;86:1258-62.

15. Ott 0J, Potter R, Hammer J, et al. Accelerated partial breast irradiation with iridium-192 multicatheter PDR/HDR brachytherapy. Preliminary results of the German-Austrian Multicenter Trial. Strahlenther Onkol 2004;180:642-9.

16. Overgaard M, Hansen PS, Overgaard J, et al. Postoperative radiotherapy in high-risk premenopausal women with breast cancer who receive adjuvant chemotherapy. Danish Breast Cancer Cooperative Group 82b trial. N Engl J Med 1997;337:949-55.

17. Overgaard M, Jensen MB, Overgaard J, et al. Postoperative radiotherapy in high-isk postmenopausal breast-cancer patients given adjuvant tamoxifen: Danish Breast Cancer Cooperative Group DBCG 82c randomised trial. Lancet 1999:353:1641-8.

18. Pierce LJ, Oberman HA, Strawderman MH, et al. Microscopic extracapsular extension in the axilla: is this an indication for axillary radiotherapy? Int J Radiat Oncol Biol Phys 1995;33:253-9.

19. Ragaz J, Jackson SM, Le N, et al. Adjuvant radiotherapy and chemotherapy in node-positive premenopausal women with breast cancer. N Engl J Med 1997;337:956-62.

20. Ragaz J, Jackson $\mathrm{S}$, Le N, et al. Postmastectomy radiation outcome in node positive breast cancer patients among N1-3 versus N4+ subset: impact of extracapsular spread. Update of the British Columbia Randomized Trial. Proc Am Soc Clin Oncol 1999;18:73a.abstract 274.

21. Sack H, Thesen N. Brustdrüse. In: Scherer E, Sack H, Hrsg. Strahlentherapie. Radiologische Onkologie, 4. Aufl. Springer: Berlin-Heidelberg-New York, 1996:661-81.

22. Stranzl $H$, Mayer $R$, Ofner $P$, et al. Extracapsular extension in positive axillary lymph nodes in female breast cancer patients. Patterns of failure and indications for postoperative locoregional irradiation. Strahlenther Onkol 2004; 180:31-7.

23. Stranzl $H$, Peintinger $F$, Ofner $P$, et al. Regional nodal recurrence in the management of breast cancer patients with one to three positive axillary lymph nodes. Outcome of patients following tangential irradiation without a separate nodal field. Strahlenther Onkol 2004;180:623-8.

24. Veronesi U, Rilke F, Luini A, et al. Distribution of axillary node metastases by level of invasion. An analysis of 539 cases. Cancer 1987;59:682-7.

25. Vicini FA, Horwitz EM, Lacerna MD, et al. The role of regional nodal irradiation in the management of patients with early-stage breast cancer treated with breast-conserving therapy. Int J Radiat Oncol Biol Phys 1997; 39:1069-76.

26. Vin-Hung V, Verschragen C. Breast-conserving surgery with or without radiotherapy: pooled-analysis for risks of ipsilateral breast tumor recurrence and mortality. J Natl Cancer Inst 2004;96:115-21.

27. Whelan TJ, Julian J, Wright J, et al. Does locoregional radiation therapy improve survival in breast cancer? A meta-analysis. J Clin Oncol 2000;6: $1220-9$.

\author{
Address for Correspondence \\ Günther Gruber, MD \\ Institute for Radiation Oncology \\ Kantonsspital Aarau \\ Tellstraße \\ 5000 Aarau \\ Switzerland \\ Phone $(+41 / 62)$ 8385-378; Fax -223 \\ e-mail:guenther.gruber@ksa.ch
}

